\title{
IGFs and IGFBPs: surrogate markers for diagnosis and surveillance of tumour growth?
}

\author{
W Zumkeller
}

\begin{abstract}
Insulin-like growth factors (IGFs), IGF receptors, and IGF binding proteins (IGFBPs) constitute the IGF system. Comprehensive data indicate that these factors play a pivotal role in tumorigenesis. Epidemiological data indicate that cancer risk is associated with high serum IGF-I values. Because dysregulation of the IGF system is a frequent pattern in malignancy, IGFs/IGFBPs might represent novel tumour markers that could be useful both for diagnosis and surveillance. (F Clin Pathol: Mol Pathol 2001;54:285-288)
\end{abstract}

Keywords: insulin-like growth factors; insulin-like growth factor binding proteins; tumour marker

The insulin-like growth factor (IGF) system plays a crucial role in normal cell proliferation and malignant transformation. ${ }^{12}$ It comprises IGF-I and IGF-II, the type I and type II receptors, ${ }^{3}$ and a family of IGF binding proteins (IGFBPs) that specifically bind IGFs. ${ }^{4}$ During the transition from the benign to the malignant state, qualitative and quantitative changes of the components of the IGF system are frequently observed. For example, increases in the type I IGF receptor are seen in human pancreatic cancer when compared with benign tissue. ${ }^{5}$ Furthermore, IGFBP dysregulation also occurs in neuroblastoma, ${ }^{6}$ nephroblastoma, ${ }^{7}$ and acute lymphoblastic leukaemia, ${ }^{8}$ among others. Thus, there is increasing evidence that IGFs and IGFBPs should be included in the panel of tumour markers used for histopathological diagnosis and serological surveillance procedures in various malignancies.

Paediatric tumours and syndromes (such as Beckwith-Wiedemann syndrome) associated with such tumours show increased IGF-II gene expression and transgenic mice overexpressing IGF-II have an enhanced risk of developing tumours. $^{9} \quad$ Immunocytochemistry showed IGF-II in choroid plexus papillomas but not in normal human choroid plexus, suggesting that IGF-II is a useful marker for the differential diagnosis of choroid plexus papilloma. ${ }^{10}$ IGF-II and $\mathrm{H} 19$, which is considered to be an oncofetal RNA and tumour suppressor gene, ${ }^{11}$ are both imprinted genes located at $11 \mathrm{p} 15$. The $\mathrm{H} 19$ gene is expressed in tumours originating from tissues that express this gene in fetal life. ${ }^{12}$ Thus, these factors show a tissue specific oncofetal pattern of expression. ${ }^{13}$ In rhabdomyosarcoma, strong IGF-II mRNA expression was observed, which was inversely correlated with the degree of tumour cell differentiation. Various other soft tissue sarcomas showed no
IGF-II mRNA expression and it was concluded that IGF-II is a potential new marker for differential diagnosis of rhabdomyosarcoma. ${ }^{14}$ There is evidence indicating that IGF-II plays a pivotal role in rhabdomyosarcoma tumorigenesis. ${ }^{15}$ Coexpression of IGF-II mRNA with the Ki-67 proliferation marker in hepatocellular carcinoma suggests that IGF-II may play an important role in the development of this particular tumour. ${ }^{16}$ In addition, the expression of H19 is under the control of the same regulatory genes as $\alpha$ fetoprotein, which is a widely used tumour marker for hepatocellular carcinoma. ${ }^{12} \mathrm{H} 19$ was present in 13 of 18 cases, whereas staining for $\alpha$ fetoprotein was positive in only nine of 18 cases. ${ }^{17}$ Earlier reports indicated that $\mathrm{H} 19$ gene expression in human bladder carcinomas was associated with a more malignant grade. ${ }^{18}$ It was suggested that $\mathrm{H} 19$ is an oncodevelopmental marker for bladder tumour progression and that this gene has oncogenic properties in this type of tumour. ${ }^{19}$

Raised serum IGFBP-1 values have been reported in patients with primary liver cancer ${ }^{20}$ and ovarian cancer. ${ }^{21}$ Whether these serum concentrations of IGFBP-1 are related to tumour cachexia or to production by the tumour itself is unclear. In the serum of patients with non-islet cell tumour hypoglycaemia, free IGF-I and IGF-II, in addition to IGFBP-1 and IGFBP-2 values, are raised. ${ }^{22}$

Consistently increased concentrations of IGFBP-2 have been described in serum and cyst fluids surrounding tumours of different histology, such as lung tumours, ${ }^{23}$ Wilms's tumours, ${ }^{7}$ prostate cancer, ${ }^{24}{ }^{25}$ colorectal tumours, ${ }^{26}$ ovarian cancer, ${ }^{27} 28$ acute lymphoblastic leukaemia, ${ }^{8}$ and brain tumours. ${ }^{15}$

Increased IGF-I and decreased IGFBP-3 concentrations are found in patients with lung cancer in comparison with control subjects, so that measuring those factors might be useful for the assessment of lung cancer risk. ${ }^{29}$ IGFBP-2 serum concentrations were significantly increased in patients with lung cancer compared with normal controls. ${ }^{30}$

\section{Prostate cancer}

Plasma IGF-I is a predictor of prostate cancer risk. ${ }^{31}$ High IGF-I and low IGF-II serum values are independently associated with increased risk of prostate cancer. ${ }^{32}$ The IGF-I/prostate specific antigen (PSA) ratio significantly improved the detection of prostate cancer over the use of PSA alone. ${ }^{33}$ Stattin et al found an association between raised plasma IGF-I and increased prostate risk, ${ }^{34}$ whereas Finne et al found no such association. ${ }^{35}$ Another study showed a significant association between low serum concentrations of IGF-I and prostate cancer. $^{36}$ The biological importance of these
Accepted for publication 21 June 2001 
data is less apparent. High IGF-I values may be associated with prostate cancer risk and the identification of raised serum IGF-I values might be useful in chemoprevention strategies. IGFBPs act as a storage pool and can inhibit or enhance IGF-mediated effects. ${ }^{37}$ Increased production of IGFBP-2 by tumours may constitute an autocrine mechanism whereby enhanced tumour growth and invasion is maintained. There may be a possible role for tumour suppressor genes altered in malignancies leading to increased IGFBP-2 expression, thus increasing tumour invasiveness as a result of enhanced mitogenic action of IGF-I. Recently, a silencer domain of the rat IGFBP-2 gene that contains a target sequence for the retinoblastoma gene product was identified. ${ }^{38}$ The raised serum concentrations of IGFBP-2 in patients with prostate cancer were related to the concentration of PSA, ${ }^{24}$ which is also an IGFBP-3 protease and thus alters IGFIGFBP-3 interactions. ${ }^{39}$ Serum IGFBP-2 values were significantly higher in patients with prostate carcinoma and high PSA than in those with normal PSA. $^{40}$ High grade prostate intraepithelial neoplasia showed enhanced IGFBP-2 and IGFBP-3 mRNA expression, but IGFBP-3 protein concentrations were significantly decreased in malignant cells. ${ }^{41}$ It appears that as prostate tissue progresses from the benign to the malignant state, IGFBP-2 immunoreactivity in the prostatic luminal epithelial cells increases and that of IGFBP-3 decreases. ${ }^{42}$ IGFBP-5 immunoreactivity was also significantly increased in malignant prostate epithelium compared with benign epithelium. ${ }^{43}$ Expression of IGFBP-2 and IGFBP-5 was higher, whereas IGFBP-3 was lower, in high versus low Gleason score prostate cancer. ${ }^{44}$ It was also suggested that increases in IGF-I and intact IGFBP-3 values are positively associated with the presence of prostate carcinoma in patients with rather low PSA values, and that measurement of IGF-I and intact IGFBP-3 may be helpful for discriminating between prostate carcinoma and benign prostatic hyperplasia. ${ }^{45}$ Clinical studies have been proposed to clarify whether measurement of IGF-I and IGFBP-3 in addition to PSA could improve the identification of men at high risk for prostate cancer. ${ }^{46}$

\section{Colorectal cancer}

Serum concentrations of IGF-II were increased in patients with colorectal adenomas compared with normal controls, indicating that IGF-II may be a tumour marker for these adenomas, which are known precursors of colorectal carcinomas. ${ }^{47}$ IGFBP-2 was raised in patients with colorectal cancer and, in combination with carcinoembryonic antigen, showed high sensitivity for colorectal cancer, and could therefore be used for surveillance of cancer in patients with colorectal cancer. ${ }^{26}$ IGFBP-2 mRNA expression is increased in human colorectal cancer cells, indicating that IGFBP-2 plays an autocrine role. ${ }^{48}$ Increasing concentrations of IGFBP-1 were associated with a significant decrease in colorectal cancer risk. $^{49}$ Therefore, high IGF-I and IGFBP-3 values may be markers for colorectal cancer risk. $^{50}$

\section{Breast cancer}

The risk of breast cancer is reduced in women who experienced pre-eclampsia during pregnancy or who were born to a mother with preeclampsia. Pre-eclampsia is associated with hormonal alterations, including a reduction in IGF-I and an increase in IGFBP- $1 .^{51}$ Thus, IGF-I and IGFBP-1 values could in this circumstance represent factors that determine a lifelong risk for breast cancer. Epidemiological studies have indicated an association between serum IGF-I values and cancer risk but have not established causality. ${ }^{52}$ Lower serum concentrations of IGFBP-1, IGFBP-3, and IGFB- 6 were found in patients with breast cancer, thus increasing the bioavailability of IGF-I..$^{53}$ The reduction of IGF-II after surgery for breast cancer was more pronounced in malignant tumours than in benign disease, and this was directly related to the size of the removed tumour. ${ }^{54}$ It remains to be elucidated whether determination of IGF-II contributes to early detection of tumour recurrence.

\section{Other cancers}

Not only do ovarian cancer tissues express IGFBP-2 preferentially, ${ }^{55}$ but the increased IGFBP-2 cyst fluid values mirror overproduction by the tumour itself, with IGFBP-2 mRNA expression being highest in invasive tumours. ${ }^{28}$ IGFBP-2 concentrations correlated positively with the highly sensitive serum tumour marker, cancer antigen 125 (CA 125), in patients with ovarian cancer. ${ }^{56}$

Increased IGFBP-2 concentrations have also been reported in patients with acute lymphoblastic leukaemia ${ }^{57}$ and, in general, increased serum IGFBP-2 concentrations coincide with higher detection rates of IGFBP-2 mRNA transcripts in leukaemia cells. ${ }^{8}$ Previous investigations had suggested that high serum concentrations of IGFBP-2 in patients with acute lymphoblastic leukaemia may indicate an increased risk of relapse..$^{58} 59$

Patients with malignant brain tumours showed increased IGFBP-2 concentrations in cerebrospinal fluid and, furthermore, children with various peripheral tumours were found to have higher serum IGFBP-2 values, which returned to normal during complete remission. ${ }^{60}$ In meningiomas, a high IGF-II/ IGFBP-2 mRNA ratio has been depicted as a sign of biologically aggressive behaviour. ${ }^{61}$ In gliomas, a highly significant correlation between IGFBP-2 cyst fluid values and immunohistochemistry and tumour grading was found. ${ }^{62}$

Patients with metastatic adrenocortical tumours had significantly higher IGFBP-2 plasma concentrations than normal controls and IGFBP-2 values in these patients were inversely correlated with their survival. ${ }^{63}$ Tumour cell growth appears to be modulated by IGFBPs in different ways. ${ }^{64}$

In carcinoma in situ (CIS) of the testis, IGFBP-5 immunoreactivity was enhanced, so 
that IGFBP-5 might be a novel tumour marker for CIS ${ }^{65}$ It needs to be established whether patients with tumours of the testis also have increased IGFBP-5 values in their serum.

In conclusion, IGFs and IGFBPs are secreted by several tumours and modulate their malignant behaviour. The genes encoding IGF-II and IGFBP-2 are upregulated in childhood malignancies, and these factors may therefore represent valuable tumour markers because they mirror the oncofetal pattern of expression. ${ }^{13}$ The consistent correlation between IGFBP overexpression and tumour grading or invasiveness could indicate their usefulness as a potential prognostic factor, which might predict outcome. Because of the pronounced expression of the IGF system seen during malignant transformation, these factors may also represent targets for therapeutic intervention.

1 Baserga R. The insulin-like growth factor receptor: a key to tumor growth? Cancer Res 1995;55:249-52.

2 Werner H, LeRoith D. The role of the insulin-like growth factor system in human cancer. Adv Cancer Res 1996;68: 183-223.

3 Werner H, LeRoith D. The insulin-like growth factor-I receptor signaling pathways are important for tumorigenesis and inhibition of apoptosis. Crit Rev Oncog 1997;8:7192.

4 Clemmons DR. Role of insulin-like growth factor binding proteins in controlling IGF actions. Mol Cell Endocrino 1998;140:19-24.

5 Bergmann U, Funatomi H, Yokoyama M, et al. Insulin-like growth factor-I-receptors overexpression in human pancreatic cancer: evidence for autocrine and paracrine roles. atic cancer: evidence for aut

6 Grellier P, De Galle B, Babajko S. Expression of insulin-like growth factor-binding protein 6 complementary DNA alters neuroblastoma cell growth. Cancer Res 1998;58: 1670-6.

7 Zumkeller W, Schwander J, Mitchell CD, et al. Insulin-like growth factor (IGF)-I, -II and IGF binding protein-2 (IGFBP-2) in the plasma of children with Wilms' tumour. Eur 7 Cancer 1993;29A:1973-7.

8 Wex H, Vorwerk P, Mohnike K, et al. Elevated serum levels of IGFBP-2 found in children suffering from acute leukaemia is accompanied by the occurrence of IGFBP- 2 mRNA in the tumour clone. Br f Cancer 1998;78:515-20.

9 Rogler CE, Yang D, Rossetti L, et al. Altered body composition and increased frequency of diverse malignancies in insulin-like growth factor-II transgenic mice. $\mathcal{f} \mathrm{Biol} \mathrm{Chem}$ 1994;269:13779-84.

10 Kubo S, Ogino S, Fukushima T, et al. Immunocytochemical detection of insulin-like growth factor II (IGF-II) in choroid plexus papilloma: a possible marker for differential diagnosis. Clin Neuropathol 1999;18:74-9.

11 Hao Y, Crenshaw M, Moulton T. Tumour-suppressor activity of H19 RNA. Nature 1993;365:764-7.

12 Ariel I, Ayesh S, Perlman EJ, et al. The product of the imprinted H19 gene is an oncofetal RNA. F Clin Pathol: $M o$ Pathol 1997;50:34-44.

13 Biran H, Ariel I, de Groot N, et al. Human imprinted genes as oncodevelopmental markers. Tumour Biol 1994;15:12334.

14 Yun K. A new marker for rhabdomyosarcoma. Insulin-like growth factor II. Lab Invest 1992;67:653-64.

15 Zumkeller W. The role of insulin-like growth factor system in soft tissue sarcomas: from pathophysiology to targeted therapeutic approaches. Sarcoma 1998;2:69-76.

16 Sohda T, Oka Y, Iwata $\mathrm{K}$, et al. Co-localisation of insulin-like growth factor II and the proliferation marker MIB1 in hepatocellular carcinoma cells. F Clin Pathol 1997; 50:135-37.

17 Ariel I, Miao HQ, Ji XR, et al. Imprinted H19 oncofetal RNA is a candidate tumor marker for hepatocellular carcinoma. F Clin Pathol: Mol Pathol 1998;51:21-5.

18 Ariel I, Lustig O, Schneider T, et al. The imprinted H19 as a tumor marker in bladder carcinoma. Urology 1995;45:3358.

19 Cooper MJ, Fisher M, Komitowski D, et al. Developmentally imprinted genes as markers for bladder tumor progression. F Urol 1996;155:2120-7.

20 Rutanen EM, Wahlström T, Koistinen R, et al. Placenta protein 12 (PP12) in primary liver cancer and cirrhosis. Tumour Biol 1984;5:95-102.

21 Iino K, Seppälä M, Heinonen PK. Elevated levels of a somatomedin-binding protein PP12 in patients with ovarian cancer. Cancer 1986;58:2294-7. 22 Frystyk J, Skjaerbaek C, Zapf J, et al. Increased levels of cir-
culating free insulin-like growth factors in patients with non-islet cell tumour hypoglycaemia. Diabetologia 1998;41: 589-94.

23 Reeve JG, Payne JA. Production of immunoreactive insulinlike growth factor I (IGF-I) and IGF-I binding proteins by human lung tumours. Br f Cancer 1990;61:727-31.

24 Cohen P, Peehl DM, Stamey TA, et al. Elevated levels of insulin-like growth factor-binding protein-2 in the serum of prostate cancer patients. I Clin Endocrinol Metab 1993;76: $1031-5$

25 Kanety H, Madjar Y, Dagan Y, et al. Serum insulin-like growth factor-binding protein-2 (IGFBP-2) is increased and IGFBP-3 is decreased in patients with prostate cancer: correlation with serum prostate-specific antigen. I Clin Endocrinol Metab 1993;77:229-33.

26 Renehan AG, Jones J, Potten CS, et al. Elevated serum insulin-like growth factor (IGF)-II and IGF binding protein-2 in patients with colorectal cancer. Br 7 Cancer 2000;83:1344-50.

27 Karasik A, Menczer J, Pariente C, et al. Insulin-like growth factor-I (IGF-I) and IGF-binding protein-2 are increased in cyst fluids of epithelial ovarian cancer. $\mathcal{F}$ Clin Endocrinol Metab 1994;78:271-6.

28 Kanety H, Kattan M, Goldberg I, et al. Increased insulin-like growth factor binding protein-2 (IGFBP-2) gene expression and protein production lead to high IGFBP-2 content in malignant ovarian cyst fluid. $\mathrm{Br} \mathcal{F}$ Cancer 1996;73:1069-73.

$29 \mathrm{Yu} \mathrm{H}$, Spitz MR, Mistry J, et al. Plasma levels of insulin-like growth factor-I and lung cancer risk: a case-control analysis. F Natl Cancer Inst 1999;91:151-6.

30 Lee DY, Kim SJ, Lee YC. Serum insulin-like growth factor (IGF)-I and IGF-binding proteins in lung cancer patients. f Korean Med Sci 1999;14:401-4.

31 Chan JM, Stampfer MJ, Giovannucci E, et al. Plasma insulin-like growth factor-I and prostate cancer risk: a proinsulin-like growth factor-I and prostate

32 Harman SM, Metter EJ, Blackman MR, et al. Serum levels of insulin-like growth factor I (IGF-I), IGF-II, IGFbinding protein- 3 , and prostate-specific antigen as predictors of clinical prostate cancer. $\mathcal{F}$ Clin Endocrinol Metab 2000;85:4258-65.

33 Djavan B, Bursa B, Seitz C, et al. Insulin-like growth factor 1 (IGF-1), IGF-1 density, and IGF-1/PSA ratio for prostate cancer detection. Urology 1999;54:603-6.

34 Stattin P, Bylund A, Rinaldi S, et al. Plasma insulin-like growth factor-I, insulin-like growth factor-binding proteins, and prostate cancer risk: a prospective study. $\mathcal{F}$ Natl Cancer Inst 2000;92:1910-17.

35 Finne $\mathrm{P}$, Auvinen A, Koistinen $\mathrm{H}$, et al. Insulin-like growth factor I is not a useful marker of prostate cancer in men with elevated levels of prostate-specific antigen. $\mathcal{F}$ Clin Endocrinol Metab 2000;85:2744-7.

36 Baffa R, Reiss K, El-Gabry EA, et al. Low serum insulin-like growth factor 1 (IGF-1): a significant association with prostate cancer. Tech Urol 2000;6:236-9.

37 Jones JI, Clemmons DR. Insulin-like growth factors and their binding proteins: biological actions. Endocr Rev 1995; 16:3-33.

38 Kutoh E, Margot JB, Schwander J. Identification and characterization of the putative retinoblastoma control element of the rat insulin-like growth factor binding protein-2 gene. Cancer Lett 1999;136:187-94.

39 Cohen P, Graves HC, Peehl DM, et al. Prostate-specific antigen (PSA) is an insulin-like growth factor binding protein-3 protease found in seminal plasma. F Clin Endocrinol Metab 1992;75:1046-83.

40 Ho PJ, Baxter RC. Insulin-like growth factor-binding protein-2 in patients with prostate carcinoma and benign prostatic hyperplasia. Clin Endocrinol 1997;46:333-42.

41 Tennant MK, Thrasher JB, Twomey PA, et al. Insulin-like growth factor-binding protein-2 and -3 expression in benign human prostate epithelium, prostate intraepithelial neoplasia, and adenocarcinoma of the prostate. If Clin Endocrinol Metab 1996;81:411-20.

42 Thrasher JB, Tennant MK, Twomey PA, et al. Immunohistochemical localization of insulin-like growth factor binding proteins 2 and 3 in prostate tissue: clinical correlations. F Urol 1996;155:999-1003.

43 Tennant MK, Thrasher JB, Twomey PA, et al. Insulin-like growth factor-binding proteins (IGFBP) $-4,-5$, and -6 in the benign and malignant human prostate: IGFBP-5 messenger ribonucleic acid localization differs from IGFBP-5 protein localization. F Clin Endocrinol Metab 1996;81:3783proteir
92.

44 Figueroa JA, De Raad S, Tadlock L, et al. Differential expression of insulin-like growth factor binding proteins in high versus low Gleason score prostate cancer. F Urol 1998; 159:1379-83

45 Khosravi J, Diamandi A, Mistry J, et al. Insulin-like growth factor I (IGF-I) and IGF-binding protein-3 in benign prostatic hyperplasia and prostate cancer. F Clin Endocrinol Metab 2001;86:694-9.

46 Wolk A, Andersson SO, Mantzoros CS, et al. Can measurements of IGF-I and IGFBP-3 improve the sensitivity of prostate-cancer screening? Lancet 2000;56:1902-3.

47 Renehan AG, Painter JE, O'Halloran D, et al. Circulating insulin-like growth factor II and colorectal adenomas. $\mathcal{F}$ Clin Endocrinol Metab 2000;85:3402-8.

48 Mishra L, Bass B, Ooi BS, et al. Role of insulin-like growth factor-I (IGF-I) receptor, IGF-I, and IGF binding
protein-2 in human colorectal cancers. Growth Horm IGF Res 1998;8:473-9. 
49 Kaaks R, Toniolo P, Akhmedkhanov A, et al. Serum proteins, and colorectal cancer risk in women. $\mathcal{F}$ Natl Canproteins, and colorectal cancer

50 Renehan AG, Painter JE, Atkin WS, et al. High-risk colorectal adenomas and serum insulin-like growth factors Br F Surg 2001;88:107-13.

51 Innes KE, Byers TE. Preeclampsia and breast cancer risk Epidemiology 1999;10:722-32.

52 Cohen P, Clemmons DR, Rosenfeld RG. Does the GH-IGF axis play a role in cancer pathogenesis? Growth Horm IGF Res 2000;10:297-305.

53 Kaulsay KK, Ng EH, Ji CY, et al. Serum IGF-binding protein- 6 and prostate specific antigen in breast cancer. Eur $\mathcal{7}$ Endocrinol 1999;140:164-8.

54 Holdaway IM, Lethaby $\mathrm{AE}$, Mason $\mathrm{BH}$, et al. Effect of breast surgery on serum AE, Maven BH, et al. Effect of 政 Surg Oncol 2001;

55 Krywicki RF, Figueroa JA, Jackson JG, et al. Regulation of insulin-like growth factor binding proteins in ovarian cancer cells by oestrogen. Eur $\mathcal{F}$ Car

56 Flyvbjerg A, Mogensen O, Mogensen serum insulin-like growth factor binding protein 2 (IGFBP-2) and decreased IGFBP-3 in epithelial ovarian cancer: correlation with cancer antigen 125 and tumorassociated trypsin inhibitor. F Clin Endocrinol Metab 1997; 82:2308-13.

57 Barrios V, Buno M, Pozo J, et al. Insulin-like growth factorbinding protein-2 levels in pediatric patients with growth hormone deficiency, eating disorders and acute lymphoblastic leukemia. Horm Res 2000;53:221-7.
58 Mohnike K, Kluba U, Mittler U, et al. Serum levels of insulin-like growth factor-I, -II and insulin-like growth factor binding proteins- 2 and -3 in children with acute lymphoblastic leukaemia. Eur f Pediatr 1996;155:81-6.

59 Mohnike K, Wex H, Vorwerk P, et al. High serum IGFBP-2 in acute lymphoblastic leukaemia (ALL) may be an indication for an increased risk of relapse. In: Hiddemann W, Büchner T eds. Acute leukemias VII: prognostic factors and treatment strategies. Berlin: Springer, 1997:375-8.

60 Müller HL, Oh Y, Lehrnbecher T, et al. Insulin-like growth factor-binding protein-2 concentrations in cerebrospinal fluid and serum of children with malignant solid tumors or acute leukemia. f Clin Endocrinol Metab 1994;79:42834

61 Sandberg-Nordqvist AC, Peyrard M, Pettersson H, et al. A high ratio of insulin-like growth factor II/insulin-like growth factor binding protein 2 messenger RNA as a marker for anaplasia in meningiomas. Cancer Res 1997;57: marker fo

62 Zumkeller W, Westphal M. The IGF/IGFBP system in CNS malignancy. F Clin Pathol: Mol Pathol 2001;54:237-9.

63 Boulle N, Baudin E, Gicquel C, et al. Evaluation of plasma insulin-like growth factor binding protein-2 as a marker for adrenocortical tumors. Eur f Endocrinol 2001;144:29-36.

64 Schofield P, Zumkeller W, Mahmood A, et al. Insulin-like growth factors and their binding proteins in the control of tumour cell growth. Pathol Biol (Paris) 1994;42:908-9.

65 Drescher B, Lauke H, Hartmann $M$, et al. Immunohistochemical pattern of insulin-like growth factor (IGF) I, IGF II, and IGF binding proteins 1 to 6 in carcinoma in situ of the testis f Clin Pathol: Mol Pathol 1997;50:298-303.

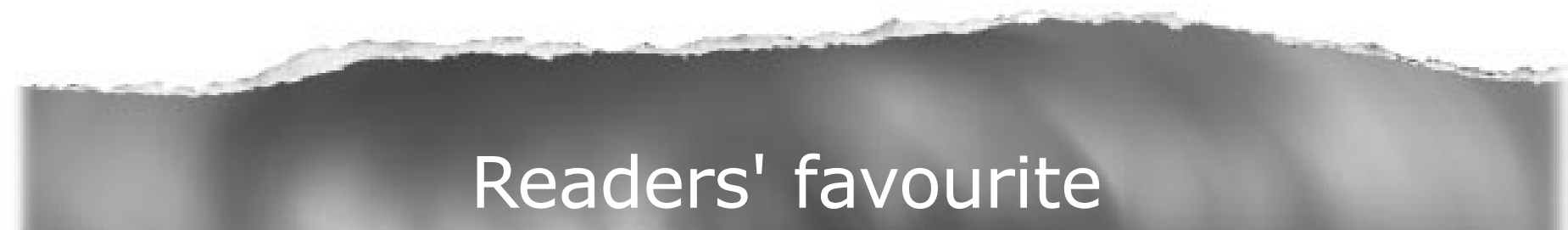

Top 10

Click on the "Top 10" button on the homepage to see which are the best read articles each month

www.jclinpath.com 